\title{
Periwinkle (Catharanthus roseus) Leaves and Lemongrass (Cympoogon citratus): An Analysis of Their Nutritional Composition, Anti-Nutritional Factors and Antioxidant Content
}

\author{
Duarah Radali $^{1 *}$ and Gupta Alka ${ }^{2}$ \\ ${ }^{1}$ Department of Food Science and Nutrition, Assam Agricultural University, Assam, India \\ ${ }^{2}$ Department of Foods and Nutrition, Sam Higginbottom University of Agriculture, \\ Technology \& Sciences, Allahabad, India \\ *Corresponding author
}

\section{A B S T R A C T}

\begin{tabular}{|l|}
\hline K e y w o r d s \\
$\begin{array}{l}\text { Nutritional and anti- } \\
\text { nutritional analysis, } \\
\text { Catharanthus roseus, } \\
\text { Cymbopogon citratus, } \\
\text { proximate analysis }\end{array}$ \\
\hline Article Info \\
\hline $\begin{array}{l}\text { Accepted: } \\
\text { 20May } 2018 \\
\text { Available Online: } \\
\text { 10 June } 2018\end{array}$ \\
\hline
\end{tabular}

\section{Introduction}

Medicinal plants, since time immemorial, have been used in virtually all cultures as a source of medicine. The widespread use of herbal remedies and healthcare preparations, as those described in ancient texts such as the Vedas and the Bible, are obtained from commonly used traditional herbs and medicinal plants. Medicinal plant products
The present study was carried out to analyze the nutritional and anti-nutritional composition and antioxidant content of the dehydrated periwinkle leaves and lemon grass, From proximate analysis it was found that dehydrated periwinkle (Catharanthus roseus) leaves and lemon grass (Cymbopogon citratus) are rich source of many nutrients. The moisture level of the dehydrated periwinkle and lemon grass leaves was found to be $8.71 \%$ and $8.56 \%$. Ash content of periwinkle leaves was found to be $4.56 \mathrm{~g} / 100 \mathrm{~g}$ and in lemon grass $6 \mathrm{~g} / 100 \mathrm{~g}$. The crude fibre obtained for periwinkle leaves was found $2.4 \mathrm{~g} / 100 \mathrm{~g}$ and in lemon grass is $4.5 \mathrm{~g} / 100 \mathrm{~g}$. The crude fat found in periwinkle leaves is $3.3 \mathrm{~g} / 100 \mathrm{~g}$, in lemon grass leaves it is $4.1 \mathrm{~g} / 100 \mathrm{~g}$. The crude protein content of periwinkle and lemongrass leaves is $5.2 \mathrm{~g} / 100 \mathrm{~g}$ and $6.5 \mathrm{~g} / 100 \mathrm{~g}$ respectively. The carbohydrate content of periwinkle leaves is $76 \mathrm{~g} / 100 \mathrm{~g}$ and in lemon grass is $70 \mathrm{~g} / 100 \mathrm{~g}$. The caloric value of the sample for periwinkle is $354 \mathrm{kcal} / 100 \mathrm{~g}$ and lemongrass is $344 \mathrm{kcal} / 100 \mathrm{~g}$. The iron content for periwinkle was found to be $27 \mathrm{mg} / 100 \mathrm{~g}$ and calcium content of periwinkle was found $320 \mathrm{mg} / 100 \mathrm{~g}$, whereas in lemon grass iron content was found $22 \mathrm{mg} / 100 \mathrm{~g}$ and calcium content was found $200 \mathrm{mg} / 100 \mathrm{~g}$. The vitamin $\mathrm{C}$ content of periwinkle and lemon grass was found to be $0.015 / 100 \mathrm{~g}$ and $2 \mathrm{mg} / 100 \mathrm{~g}$. 
clusters (Figueirinha et al., 2008). The leaves of Lemongrass (Cymbopogon Citratus) present lemony characteristic flavour due to its main content, citral which present great importance to the industry. Citral, a combination of neral and geranial isomers, is used as a raw material for the production of ionone, vitamin A and beta-carotene (Carlson et al., 2001).

Catharanthus roseus, the Madagascar periwinkle or rosy periwinkle, is an attractive small sub shrub with graceful pink or white salver form flowers. Madagascar periwinkle was used in traditional medicine, the periwinkle has been used for relieving muscle pain, depression of the central nervous system, also used for applying to wasp stings and to heal wounds. Its application ranges widely from the prevention of diabetes to treatment of stomach ache. (Gajalakshmi et al., 2013). Alkaloids isolated from $C$. roseus are hypotensive, sedative and have tranquilising properties and are anti-cancerous. Traditionally it is used for relieving muscle pain, depression of central nervous system and wasps stings. Its application ranges from prevention of cancer, cancer treatment, antidiabetic, stomachic, reduces high blood pressure, externally against nose bleeding, sore throat and mouth ulcer. (Nammi et al., 2003).

\section{Materials and Methods}

The experiment was conducted in the Nutritional Research Laboratory, Department of Foods and Nutrition, Ethelind School of Home Science, Sam Higginbottom University of Agriculture, Technology and Sciences (Deemed to be University) Allahabad, U.P.

The details of the materials, experimental procedure and techniques to be adopted during the course of the investigation were as follows:

\section{Experimental site}

The present investigation was carried out in the Nutrition Research Laboratory, Foods and Nutrition, Ethelind School of Home Science, SHUATS, Allahabad.

\section{Procurement of raw materials}

Periwinkle (Catharanthus roseus) leaves and Lemongrass (Cymbopogon citrates) were collected from the field of Department of Horticulture, Sam Higgingottom University of Agriculture, Technology and Sciences.

Leaves were washed with the help of clean water so as to remove the dirt and other disease causing organisms.

\section{Dehydration process of periwinkle and lemongrass leaves}

Periwinkle/lemon grass leaves, after washed and trimmed, were spread on flat wooden trays and allowed to dry for 15 hours at $60^{\circ}$ $65^{\circ} \mathrm{C}$. Dehydration process was continued till the moisture becomes 6-8\%. Then these leaves were ground into powder form and packed in air tight containers.

\section{Nutritional Composition of lemongrass and periwinkle leaves powder}

\section{Proximate analysis}

Chemical estimation of moisture, ash, protein, fat and fibre content was done by AOAC, using standard procedure.

Methods described by AOAC, was used for determination of chemical composition of selected product, this included estimation of moisture, ash, crude fat, protein, crude fiber and carbohydrate was calculated by difference method and energy was estimated by calculation method. 


\section{Minerals content}

Iron and calcium was estimated by using standard procedures.

\section{Vitamin C}

Vitamin C was estimated using standard procedures.

\section{Antioxidant composition}

Determination of Total Phenol Content by (Singleton et al.,) and Determination of Radical scavenging Activity by DPPH Radical Scavenging Method (Brand et al.,1995)

\section{Antinutritional composition}

Phytate was estimated by calorimetric methods as describe by Sadasivam (1996) and the total Oxalate in the form of oxalic acid was estimated by the method of Gupta (2007).

\section{Results and Discussion}

Table 1 shows the proximate composition, mineral and vitamin content of the dehydrated periwinkle leaves and lemon grass leaves. The moisture level of the dehydrated periwinkle and lemon grass leaves was found to be $8.71 \%$ and $8.56 \%$. Moisture content is among the most vital and mostly used measurement in the processing, preservation and storage of food. So the results supports the practice of storage of the leaves in dehydrated form as the low moisture content of these leaves will prevent microbial attack and allows high storage capacity.

Ash content is generally taken to be a measure of the mineral content of the original food. The high value of ash content of periwinkle leaves $(4.56 \mathrm{~g} / 100 \mathrm{~g})$ and lemon grass (6 $\mathrm{g} / 100 \mathrm{~g}$ ) leaves were indicative of high mineral (especially the macro-minerals) content of these leaves. The ash content of the periwinkle leaves sample was slightly higher than those reported by Choudhary et al., (2014) i.e $3.89 \mathrm{~g} / 100 \mathrm{~g}$; ash content of lemon grass was found slightly lower as than those reported by Asaolu et al., (2009) i.e 7.83g/100 g.

Crude fibre in food or plant is an indication of the level of non-digestible carbohydrate and lignin. The crude fibre obtained for periwinkle leaves was found $2.4 \mathrm{~g} / 100 \mathrm{~g}$, which is slightly lower than those reported by Choudhary et al., (2014) i.e $1.04 \mathrm{~g} / 100 \mathrm{~g}$. The crude fibre obtained from lemon grass is $4.5 \mathrm{~g} / 100 \mathrm{~g}$, which is also found comparatively lower than those reported by Asaolu et al., (2009) i.e 9.28 g/ 100 g. High fibre content in diets have been reported to result in increased removal of carcinogens, potential mutagens, steroids, bile acids and xenobiotics by binding or absorbing to dietary fibre components and be rapidly excreted, hence these wastes will have health promoting benefits for the ruminants and nonruminants (Ayoola and Adeyeye, 2009).Crude fat determines the free fatty lipids of a product. This property can be used as the basis in determining processing temperatures as well as auto-oxidation which can lead to rancidity (affect flavour of food). The crude fat found in periwinkle leaves is $3.3 \mathrm{~g} / 100 \mathrm{~g}$ which is comparatively lower than those reported by Choudhary et al., (2014) i.e $19.68 \mathrm{~g} / 100 \mathrm{~g}$ whereas fat found in lemon grass leaves is $4.1 \mathrm{~g} / 100 \mathrm{~g}$ which is comparatively similar to those reported by Asaolu et al., (2009) i.e $5.10 \mathrm{~g} / 100 \mathrm{~g}$. The low content of fat of both the medicinal leaves indicate enhancement of storage life due to reduction in chance of developing rancid flavour.

The crude protein content of periwinkle and lemongrass leaves is $5.2 \mathrm{~g} / 100 \mathrm{~g}$ and $6.5 \mathrm{~g} / 100 \mathrm{~g}$ respectively, which is found similar to the findings by Choudhary et al., (2014) i.e $7.05 \mathrm{~g} / 100 \mathrm{~g}$ and Asaolu et al., (2009) i.e 4.56 $\mathrm{g} / 100 \mathrm{~g}$. 
Table.1 Proximate analysis, minerals and vitamin content of dehydrated periwinkle leaves and lemon grass leaves (per 100g)

\begin{tabular}{|l|l|l|}
\hline Nutrients & $\begin{array}{l}\text { Periwinkle leaves } \\
\text { (Nutritive Value) }\end{array}$ & $\begin{array}{l}\text { Lemongrass leaves } \\
\text { (Nutritive Value) }\end{array}$ \\
\hline Moisture (\%) & 8.71 & 8.56 \\
\hline Ash (g) & 4.5 & 6 \\
\hline Carbohydrate (g) & 76 & 70.4 \\
\hline Protein (g) & 5.2 & 6.5 \\
\hline Fat (g) & 3.3 & 4 \\
\hline Crude fiber (g) & 2.4 & 4.5 \\
\hline Energy (Kcal) & 354 & 344 \\
\hline Calcium (mg) & 340 & 300 \\
\hline Iron (mg) & 27 & 22 \\
\hline Vitamin C (mg) & 0.02 & 2 \\
\hline
\end{tabular}

Antioxidant and Anti nutritional composition of dehydrated periwinkle and lemon grass leaves (per 100g)

\begin{tabular}{|l|c|c|}
\hline Nutrients & $\begin{array}{c}\text { Periwinkle leaves powder } \\
\text { (Nutritive value) }\end{array}$ & $\begin{array}{c}\text { Lemongrass leaves powder } \\
\text { (Nutritive value) }\end{array}$ \\
\hline Poly phenols (mg) & 139 & 112 \\
\hline DPPH (\%) & 45 & 41 \\
\hline Oxalate(mg) & 3.2 & 2.5 \\
\hline Phytate (mg) & 0.8 & 4.8 \\
\hline
\end{tabular}

The high carbohydrate content of both periwinkle leaves $(76 \mathrm{~g} / 100 \mathrm{~g})$ and lemon grass leaves $(70 \mathrm{~g} / 100 \mathrm{~g})$ shows that both leaves are very good source of energy which is found higher than those reported by Choudhary et al., (2014) i.e $46.02 \mathrm{~g} / 100 \mathrm{~g}$ and Asaolu et al., (2009) i.e $55 \mathrm{~g} / 100 \mathrm{~g}$.

The caloric value of the sample for periwinkle $(354 \mathrm{kcal} / 100 \mathrm{~g})$ and lemongrass $(344 \mathrm{kcal} / 100$ g) is found slightly lower when compared with those reported by Choudhary et al., (2014) i.e $369.37 \mathrm{kcal} / 100 \mathrm{~g}$ and Asaolu et al., (2009) i.e $360.55 \mathrm{kcal} / 100 \mathrm{~g}$.

The iron content for periwinkle was found to be $27 \mathrm{mg} / 100 \mathrm{~g}$ which is found much lower than those reported by Choudhary et al., (2014) i.e $154.39 \mathrm{mg} / 100 \mathrm{~g}$ and calcium content of periwinkle was found 320 $\mathrm{mg} / 100 \mathrm{~g}$, which is found higher than those reported by Choudhary et al., (2014) i.e $232.90 \mathrm{mg} / 100 \mathrm{~g}$ whereas for lemon grass iron content was found $22 \mathrm{mg} / 100 \mathrm{~g}$ which is lower than those reported by Asaolu et al., (2009) i.e $43 \mathrm{mg} / 100 \mathrm{~g}$.

The calcium content of lemon grass was found $200 \mathrm{mg} / 100 \mathrm{~g}$ which is slightly lower than the findings of Asaolu et al., (2009) i.e $242 \mathrm{mg} / 100 \mathrm{~g}$.Calcium is essential for bone and teeth formation and development, blood clotting and for normal functioning of heart, nervous system and muscles. Calcium deficiency can lead to ricket, osteomalacia and tooth decay Michael (2006). The vitamin $\mathrm{C}$ content of periwinkle and lemon grass was found to be $0.015 / 100 \mathrm{~g}$ and $2 \mathrm{mg} / 100 \mathrm{~g}$. 
Table 4.1.2 shows the antioxidant and antinutritional composition of periwinkle and lemon grass leaves. Antioxidant found in dehydrated periwinkle leaves (per 100 grams) obtained by chemical analysis- here polyphenols is found to be $139 \mathrm{mg}$ which is lower than those reported by Srivastava et al., (2013) i.e $163.02 \mathrm{mg}$ and DPPH radical scavenging activity was found to be $45.18 \%$ which is similar to those reported by Bhutkar and Bhise (2011) i.e 65\%.

Polyphenol found in lemon grass is 112.4 $\mathrm{mg} / 100 \mathrm{~g}$ which is supported by findings of Tangkanakul (2009) i.e $120.57 \mathrm{mg} / 100 \mathrm{~g}$ and DPPH radical scavenging activity was found $41 \%$ which is supported by the findings of Garg et al., (2012) i.e.51.4\%.

Besides the nutritional importance of plants, they also contain certain anti nutritional factors such as phytate and oxalate. It is suffice to say that these anti nutrients reduce the bioavailability of nutrients in the food and plants (Akindahunsi and Salawu, 2005). Oxalate and Phytate found in periwinkle is $3.2 \mathrm{mg} / 100 \mathrm{~g}$ and $0.8 \mathrm{mg} / 100 \mathrm{~g}$. The level of Phytate found in leaves has no known toxicity and is not known to cause mutagenic activity. It may have more therapeutic value when added to water rather than when naturally absorbed in foods as it is difficult to free from fibres. Oxalate and Phytate present in lemon grass found to be $2.5 \mathrm{mg} / 100 \mathrm{~g}$ and $4.5 \mathrm{mg} / 100 \mathrm{~g}$ respectively. The low levels of Phytate and oxalate is of nutritional significance because it may allow bioavailability of many essential minerals and therapeutic effects of the leaves (Akindahunsi and Salawu, 2005).

It is concluded that dehydrated composite leaves powder of periwinkle and lemon grass are rich source of iron, calcium, carbohydrate, energy etc. these are also rich source of antioxidants anti nutritional factors which proves to be beneficial for our body and it can be can be successfully incorporated in the preparation of the food products. Incorporation of dehydrated medicinal leaves powder mixture will enhance the nutritive value of traditional recipes improving their micronutrient content, antioxidant content and radical scavenging activity

\section{References}

Abubakar, M.C., Ukwuani, A.N., and Shehu, R.A., (2008). Phytochemical screening and Antibacteria activity of Tamarindus indica pulp extract. Asian J. Biochem. 3 (2): 134-138.

Akindahunsi, A. A. and Salawu, S.O. (2005) Phytochemical screening and nutrientantinutrient composition of selected tropical green leafy vegetables. African Journal of Biotechnology. 4(6): 497501 ,

AOAC, (2005). Association of Official Analytical Chemist's, $18^{\text {th }}$ edt.Washington DC, UAS.

Asaolu, M.F., Oyeyemi, O.A., and Olanlokun, J.O., (2009) Chemical Compositions, Phytochemical Constituents and in vitro Biological Activity of Various Extracts of Cymbopogon citratus. Pakistan Journal of Nutrition.8 (12): 1920-1922

Ayoola, P.B, Adeyeye, A. (2009) Proximate Analysis and Nutrient Evaluation of Some Nigerian Pawpaw Seeds Varieties. Sci. Focus. 14 (4): 554-558.

Bhutkar, M.A., and Bhise, S.B., (2011) Studies on Antioxidant Properties of Catharanthus rosea and Catharanthus alba. Current Pharma Research. 1(4), 337-340.

Brand, W.W., Cuvelier, M.E., and Berset, C. (1995) "Use of a free radical method to evaluate antioxidant activity" Food Science and Technology 28: 25-30.

Carlson, L.H.C., Machad, C.B.S., Pereira, L.K., and Bolzan, A., (2001) Extraction 
of lemongrass essential oil with dense carbon dioxide, Journal of Supercritical Fluids. 2(1): 33-39

Choudhary, S., Bisla, G., and Chaudhary, V., (2014). Proximate nutrient composition and anti-nutrient analysis of Catharanthus roseus (Sadabahar) leaves explore their hypoglycemic potential Chem Xpress, 7(3):86-91.

Edeoga, H.O., Okwu, D.E., Mbaebie, B.O., (2005). Phytochemical constituents of some Nigeria Medicinal plants. African. J. Biotech. 4 (7):685-688.

Figueirinha, A., Paranhos, A., PerezAlonso, J. J., Santos-Buelga, C., \& Batista, M.T. (2008). Cymbopogon citratus leaves. Characterisation of flavonoids by HPLCPDA-ESI/MS and an approach to their potential as a source of bioactive polyphenols. Fd. Chem, 110, 718-728

Gajalakshmi, S., Vijayalakshmi, S., and Devi, R. V., (2013). Pharmacological Activities of Catharanthus Roseus: A Perspective Review. International Journal of Pharma and Bio Science. 4(2): $431-439$.

Garg, D., Muley, A., Khare, N., and Marar, T., (2011) Comparative Analysis of Phytochemical Profile and Antioxidant Activity of Some Indian Culinary Herbs. Research Journal of Pharmaceutical, Biological and Chemical Sciences. 3(3):343-354
Gupta, A.K. (2007). Practical manual of agricultural chemistry, Analysis of plant, Food and Biological Samples. $3^{\text {rd }}$ ed

Joshi, P., and Mathur, B., (2010). Preparation of value added products from the leaf powders of dehydrated less utilized green leafy vegetables. Journal of Horticulture and Forestry. 2(9): 223 228

Nammi, S., Boini, M.K., Lodagala, S.D., and Behara, R.B.S (2003) The juice of fresh leaves of Catharanthus roseus Linn. reduces blood glucose in normal and alloxan diabetic rabbits. The official journal of the International Society for Complementary Medicine Research (ISCMR) 3:4

Park, H. M., Heo, J., and Park, Y., (2011). Calcium from plant sources is beneficial to lowering the risk of osteoporosis in postmenopausal Korean women. Nutrition Research 31(1): 27-32

Singleton V.L, Orthofer R, Lamuela-Raventos R.M. (1999). Analysis of total phenols and other oxidation substrates and antioxidants by means of FolinCiocalteaue Reagents. Methods Enzymol.299: 152-178.

Srilakshmi, B. (2007). Food Sciences" 5th Edition New Age International Publishers; 194- 198.

\section{How to cite this article:}

Duarah Radali and Gupta Alka. 2018. Periwikle (Catharanthus roseus) Leaves and Lemograss (Cympoogon citratus): An Analysis of Their Nutritional Composition, Anti-Nutritional Factors and Antioxidant Content. Int.J.Curr.Microbiol.App.Sci. 7(06): 2130-2135. doi: https://doi.org/10.20546/ijcmas.2018.706.253 